DOI: 10.14526/2070-4798-2019-14-3-51-54

\title{
Peculiarities of the axiological component of sports culture in students
}

\author{
Vladimir M. Krylov, Anastasiya V. Krylova*, Tatiana A. Ponomareva \\ Sterlitamak branch of Bashkir State University \\ Sterlitamak, Russia \\ ORCID: 00oo-0oo1-7514-2861, Klrylova.s.v@inbox.ru \\ ORCID: 0000-0003-0058-2947, Sifk_nayka@mail.ru* \\ ORCID: oooo-ooo1-7237-4691, Reklamaso@yandex.ru
}

\begin{abstract}
The most resource type of activity that allows to achieve the implementation of state objectives in the field of physical culture and sports in terms of increasing the degree of the population involvement in sports activities is mass sports. Taking into account features of psycho-physical conditions of students, the indicator of this contingent involvement should be the maximum and its achievement is possible only in the course of sports activity. In this connection, the question of formation and development of sports culture in students which intentional basis is an axiological component is actualized. Materials. The specificity of the axiological component of sports culture lies in dualism, the unity of its integrative and conflict nature. The article investigates the axiological component of sports culture in students of nonphysical training profile in order to define the determinants of formation and development of this type of culture and increase the degree of the studied contingent involvement in sports activities. Research methods. Analysis and generalization of scientific and methodological literature, the author's diagnostic method of identifying the leading motive of activity. Results. As a result of the study, it was found that among students who do not engage in mass sports, the utilitarianpragmatic type of sports culture prevailed (67\%), and among boys and girls the result is different. Humanistic values are more peculiar to girls $(\mathrm{p} \leq 0.05)$. The differences are statistically significant by Fisher's angular distribution criterion. Among students-athletes (engaged in sports section on the basis of the University), the humanistic type of sports culture prevails. There are no significant differences between boys and girls. Conclusion. The Structure of the axiological component of sports culture is represented by motivational-value modules. These modules, in an enlarged version, allow us to distinguish two types of sports culture: utilitarian-pragmatic and humanistic. In the course of empirical research, we have established that the values belonging to the humanistic group are either the main determinants of a high degree of involvement in physical culture and sports activities, or are formed through this involvement. As pedagogical conditions to increase the degree of involvement in physical culture and sports activity of students will be the following ones: formation of mass sports image as the environment for increase and realization of own potential, achievement of success. The realization of this condition is possible in the context of lectures, subject to an increase in the share of the theoretical module, revealing the main aspects of Olympism, the Olympic movement and the Olympic Games. In turn, pedagogical means of students humanistic sports culture development will be directly process of occupations by mass sports.
\end{abstract}

Keywords: sports culture, axiological component of the personality sports culture, pedagogical conditions of the personality sports culture development in students.

For citation: Vladimir M. Krylov, Anastasiya V. Krylova*, Tatiana A. Ponomareva. Peculiarities of the axiological component of sports culture at students. Russian Journal of Physical Education and Sport. 2019; 14(3): 51-54. DOI: 10.14526/2070-4798-2019-14-3-51-54

\section{INTRODUCTION}

During the last ten years one of the most highpriority tasks of state policy in the sphere of physical culture and sports is the increase of Russian Federation citizens rate systematically engaged in physical training and sports. It is planned to increase this rate among the student youth by one third in comparison with the year 2010. The actuality of this task is determined by a number of issues such as: high sickness level and low level of school children and applicants physical condition. So, according to the data from the Strategy of developing physical culture and sports in the Russian Federation for the period until 2020, it is noted that only 14 percent of school leavers are considered to be apparently healthy, and over 40 percent of young men of military age fail to meet the requirements claimed by the military service in terms of their physical condition. However, solution to the problems mentioned above demands not so much massive 
participation in physical training as changing the degree of subject involvement in this type of social activity. Thus, in the target points of the Strategy it is stated that the quantity of weekly physical activity of the population must be 8-12 hours including no less than 3-4 single trainings depending on age and other peculiarities of citizens. Taking into account features of psycho-physical conditions of the considered contingent, this indicator for the student (not having any health limitations) should be the maximum. It becomes obvious that the most resource type of activity that allows to achieve the implementation of the set objectives is mass sports, because unlike physical culture it is characterized by the following specific properties: systematic character of trainings, high degree of involvement into training process while retaining health saving orientation of the target point.

In this connection, there appear two urgent issues: involvement of students into mass sports and increase of training activity effectiveness by sport types on the basis of the University. Solution to the following issues seems to be possible by means of establishing and developing the student sports culture as a core intention with respect to style of living.

To define pedagogical conditions for establishing and developing the students sports culture it is necessary to find out its main determinants. And if a whole number of research papers was dedicated to the questions of studying the content of sports culture components among physical training university students (Burtsev V.A., Burtseva E.V., Lubysheva L.I., Stolyarov V.I., Seliverstova I.N., Satemirova Sh.A., Tumarova K.B., Sharipov M.F. etc.), then the same question but relating to students of non-physical training profile was not given consideration.

Guided by the proportion model of the personality sports culture structural components, proposed by Seliverstova I.N. and her co-authors, it is exactly an axiological component which is intentional; its structure is represented by motivational-value modules [7].

Therefore, studying the axiological component of sports culture among students of non-physical training profile engaged in mass sports, it is possible to define main determinants and pedagogical conditions for developing this type of the personality culture, that in its turn will allow to increase the degree of students involvement into sports and training activity.

The Purpose of the article is to investigate the content of the sports culture axiological component among students of non-physical training profile.

Objectives:

1. To analyze the essence of such phenomenon as "sports culture".
2. To investigate the content of the axiological component of sports culture among students of non-physical training profile.

3. To define determinants of developing sports culture in students.

Methods: analysis and generalization of scientific and methodological literature, the author's diagnostic method of identifying the leading motive of activity.

\section{RESULTS AND DISCUSSION}

In consideration of the category "sports culture", we define its several aspects analogous to the society culture in whole and physical culture in particular.

In a social and cultural aspect, sports culture is represented as a set of specific values and knowledge realized in the process of training and competitive activities. In this respect, V.I.Stolyarov and S.Yu. Barinov define sports culture as values which are tried-and-tested in the society and passed down through the generations; these values appear during the course of competitions and sport preparation for them $[1,8]$.

In an activity aspect, sports culture is regarded as a type of physical culture and sports activity. V.I.Stolyarov and S.Yu.Barinov represent it in the form of social-pedagogical processes and relations, which appear during the course of competitions and sport preparation for them $[1,8]$. In research papers by L.I.Lubysheva sports culture is considered as an integrative personal formation which includes the system of means, methods and results of physical culture and sports activity aimed at perception, reproduction, creation and distribution of physical culture and sports values and technologies [4, 5]. In the view of K.B.Tumarov and V.A. Burtsev, sports culture is a system-organized and personconditioned integral characteristic of man as a subject of sports activity, which is adequate to targets and contents and provides its practical realization on the personally and socially acceptable level $[2,9]$. Here we can also trace the consideration of sports culture as a criterion for development of personality.

Analyzing sports culture as a social phenomenon it becomes obvious that, being a part of physical culture as a set of values, it accumulates such specific values which, forming requirements and motives, determine the personality orientation in the field of physical culture and sports activity. Herewith, the specificity of value aspect of sports culture lies in dualism, the unity of its integrative and conflict nature $[8,10]$. It is connected with the fact that a competition/contest as a foundational characteristic of sport is in itself a conflict system and environment which allows to satisfy requirements in power and realization of aggressive motives [10]. Upon that, sports activity, namely in the area of mass sports, 
is represented in the form of active and practical comparison of capabilities of one person with the capabilities of the other one (N.N. Vizitey), that creates conditions for effective communication and full development of human personality. The degree of domination of one or the other group of values (humanistic or antihuman) depends on the environmental conditions, in other words on the character of society culture in whole, which the sports culture is built into as a part of it [8].

In view of this, we have carried out an empirical research of the axiological component of sports culture among students of non-physical training profile with an aim to define main determinants of forming and developing this type of personality culture. This research has been realized on the basis of Sterlitamak branch of Bashkir State University within 3 years (from 2016 till 2019). Test persons were the students of the 1st course both engaging in mass sports and also visiting elective courses of physical culture.

As a main method of investigation the author's diagnostic method of identifying the leading motive of activity in the sphere of mass sports was used. This method represents a set of 15 requirements discovered as a result of interrogation of 560 students engaging in mass sports. All discovered requirements were classified in the method in accordance with two groups of sports culture value: success achievement (as a dissociative value) and development of personality (as an associative/ humanistic value).

Content of method. The students were asked to make a pairwise comparison of below mentioned requirements according to the degree of their actuality expressing their opinions on special matrixes of registration form.

Table 1 - Content of method

I think that mass sport gives/will give me the following opportunities:

\begin{tabular}{|l|l|}
\hline \multicolumn{1}{|c|}{ Group } & \multicolumn{1}{|c|}{ Requirements } \\
\hline Success achievement (utilitarian-pragmatic type & Become stronger \\
\cline { 2 - 2 } of sports culture) & Be more competitive \\
\cline { 2 - 2 } & $\begin{array}{l}\text { Be in a good physical condition/have a nice body/ } \\
\text { figure }\end{array}$ \\
\cline { 2 - 2 } & Be invulnerable /Feel safe \\
\cline { 2 - 2 } & Feel the joy of victory, success achievement \\
\hline \multirow{4}{*}{$\begin{array}{l}\text { Sevelopment of personality (humanistic type of } \\
\text { Bulture) }\end{array}$} & Build up character/Develop volitional regulation \\
\cline { 2 - 2 } & $\begin{array}{l}\text { Maintain the required level of physical condition } \\
\text { and physical development }\end{array}$ \\
\cline { 2 - 2 } & Keep one's health in a good state \\
\cline { 2 - 2 } & $\begin{array}{l}\text { Have opportunity to engage in competitions for } \\
\text { internal motivation }\end{array}$ \\
\cline { 2 - 2 } & Be active socially and physically \\
\hline
\end{tabular}

Table 2 - Results of research

\begin{tabular}{|c|c|c|c|c|}
\hline \multirow[t]{2}{*}{ Group } & \multicolumn{2}{|c|}{$\begin{array}{l}\text { Engaging in sports sections } \\
(\mathrm{n}=367)\end{array}$} & \multicolumn{2}{|c|}{$\begin{array}{l}\text { Visiting elective courses of } \\
\text { physical culture }(n=384)\end{array}$} \\
\hline & Boys $(n=205)$ & Girls $(n=162)$ & Boys $(n=187)$ & Girls $(n=180)$ \\
\hline $\begin{array}{l}\text { Success achievement (utilitarian- } \\
\text { pragmatic type of sports culture) }\end{array}$ & $31 \%$ & $26 \%$ & $67 \%$ & $42 \%$ \\
\hline $\begin{array}{l}\text { Significance by Fisher's angular } \\
\text { distribution criterion }\end{array}$ & \multicolumn{2}{|c|}{$\mathrm{p} \geq 0,05$} & \multicolumn{2}{|c|}{$\mathrm{p} \leq 0,05$} \\
\hline $\begin{array}{l}\text { Развитие личности (humanistic } \\
\text { type of sports culture) }\end{array}$ & $69 \%$ & $74 \%$ & $33 \%$ & $58 \%$ \\
\hline $\begin{array}{l}\text { Significance by Fisher's angular } \\
\text { distribution criterion }\end{array}$ & \multicolumn{2}{|c|}{$\mathrm{p} \geq 0,05$} & \multicolumn{2}{|c|}{$\mathrm{p} \leq 0,05$} \\
\hline
\end{tabular}

As a result of the study, the following data was found. Among students who do not engage in mass sports, the utilitarian-pragmatic type of sports culture prevailed (67\%), and among boys and girls the result was different. Humanistic values are more peculiar to girls $(\mathrm{p} \leq 0.05)$. 
The differences are statistically significant by Fisher's angular distribution criterion. Among students-athletes (engaged in sports section on the basis of the University), the humanistic type of sports culture prevails. There are no significant differences between boys and girls.

\section{CONCLUSION}

The axiological component of the personality sports structure is intentional. Its structure is represented by motivational-value modules, specific character of which lies in its duality, unity of its integrative and conflict nature. These modules, in a scaled-up version, allow to single out two types of sports culture: utilitarian-pragmatic and humanistic. In the course of empirical research, concerning determinants of establishing and developing sports culture among students and increase of their involvement degree in physical culture and sports activity, we have found out that the values belonging to the humanistic group are either the main determinants of a high degree of involvement in physical culture and sports activities, or are formed through this involvement. There appears a necessity to carry out factor analysis. And at that, as pedagogical conditions to increase the degree of involvement in physical culture and sports activity of students not engaged in any trainings there will be the following ones, same both for boys and girls: formation of an image of mass sports as the environment for increase and realization of own potential, achievement of success. The realization of this condition is possible in the context of lectures, subject to an increase in the share of the theoretical module, revealing the main aspects of Olympism, the Olympic movement and the Olympic Games. In turn, pedagogical means of developing the humanistic sports culture of students will be directly the process of occupations by mass sports.

\section{REFERENCES}

1. Barinov S.Yu. Criteria of diagnostics of sports culture of the person. Sportivnyj psiholog. 2012; 1: 15-17 (In Russ.).

2. Burtsev V.A., Drandrov G.L., Borovik S.G. Theoretical model of sports culture of personality. Fundamental'nye issledovaniya. 2015; 2(17): 38163820 (In Russ.).

3. Vilenskiy M.Ya. Physical culture in professional value orientations of students and the process of their formation. Teoriya I praktika fizicheskoj kul'tury = Theory and practice of physical culture. 1991; 11: 2-7 (In Russ., In Engl.).

4. Lubysheva L.I. the Phenomenon of sports culture of personality in the aspect of methodological analysis. Teoriya I praktika fizicheskoj kul'tury = Theory and practice of physical culture. 2009; 3: 1013 (In Russ., In Engl.).

5. Lubysheva L.I., Zagrevskaya A.I. Structure and content of sports culture of personality. Teoriya I praktika fizicheskoj kul'tury $=$ Theory and practice of physical culture. 2013; 3: 3-15 (In Russ., In Engl.).

6. Ponomareva T.A. Intentional values of physical culture of student youth. Pedagogikopsihologcheskie I medico-biologicheskie problemy fizicheskoj kul'tury I sporta = Pedagogicopsychological and medico-biological problems of physical culture and sport. 2017; 12(1): 74-81.

7. Seliverstova I.N., Kuzmin A.M., Afanasiev A.A. Analysis of the phenomenon "sports culture of the student's personality". Internet zhurnal "Mir nauki”. 2017; 5(2). URL: http://mir-nauki.com/ PDF/21PDMN217.pdf (In Russ.)

8. StolyarovV.I.Actual problems of philosophy and sociology of sport. Teoriya I praktika fizicheskoj kul'tury = Theory and practice of physical culture. 1980; 12: 7-10 (In Russ., In Engl.).

9. Tomarov K.B. Content and organization of personality-oriented physical education of students on the basis of mini-football. Candidate's thesis. N. Chelny. 2012: 191.

10. Luschen Gunter, Sage G. The System of Sport: Problem of Methodology, Conflict and Social Stratification. Handbook of Social Science of Sport. Stipes, Champaign, Illinois. 1981: 197-213.

11. Baquet G., Van Praagh E., Berthoin S. Endurance training and aerobic fitness in young people. Sports Medicine. 2003; 15: 1127-1143.

12. Brunet J., Sabiston C.M. Social physique anxiety and physical activity: A self-determination theory perspective. Psychology of Sport and Exercise. 2009; 10: 329-335.

13. Department of Health. Be active, be healthy. London: TSO. 2009.

14. Phillips E., Davids K., Portus M. Expert performance in sport and the dynamics of talent development. Sports Medicine. 2010; 40: 271-283.

\section{Submitted: 12.08.2019}

Author's information:

Vladimir M. Krylov - Candidate of Pedagogics, Associate professor, Sterlitamak branch of Bashkir State University, 453103, Russia, Sterlitamak, Lenin Avenue, House 49, e-mail: Krylova.s.v@inbox.ru

Anastasiya V. Krylova - Candidate of Psychological Sciences, Associate professor. Sterlitamak branch of Bashkir State University, 453103, Russia, Sterlitamak, Lenin Avenue, House 49, e-mail: Sifk_ nayka@mail.ru

Tatiana A. Ponomareva - Candidate of Sociological Sciences, Associate professor. Sterlitamak branch of Bashkir State University, 453103, Russia, Sterlitamak, Lenin Avenue, House 49, e-mail: Reklamaso@yandex.ru 